\title{
A Pluralistic Approach to Protected Area Governance: Indigenous Peoples and Makuira National Park, Colombia
}

Julia Margareta Premauer, ${ }^{\prime *}$ and Fikret Berkes ${ }^{2}$

\begin{abstract}
Based on a study of collaborative governance (Spanish cogobierno, literally co-government) in Makuira National Park overlapping with an Indigenous collective territory of the Wayúu people recognised by the Government of Colombia, we analyse how Indigenous rights and conservation interests are negotiated between the national parks authority and local Indigenous governing authorities. Recognised common interests provide a basis for collaboration in protected area governance even where conflicting interests exist. The arrangements arrived at by negotiation incorporate Indigenous governance and parks conservation objectives, enabling territorial use planning which allows for both conflict management and protected area management. Ongoing collaborative governance based on common interests, brings both benefits and trade-offs. The Wayúu give up part of their self-determination rights and the Park gives up part of the ideals of ecosystem conservation based on biological criteria. The strategic alliance works because it is based on the recognition of the legitimacy of Indigenous governing authority, the Parks' role in protecting Wayúu territory, and the complementary strengths of the two parties. The core message of the case is that designing an inclusive and broad practice of conservation requires an approach involving processes that acknowledge common interests and trade-offs for both parties.
\end{abstract}

Keywords: Indigenous rights, Trade-offs, Co-management, Co-governance, Biodiversity Conservation, Latin America

\section{INTRODUCTION}

In recent years conservation practice has shifted to involve Indigenous peoples and local communities in protected area (PA) management (Brechin et al. 2002; Bawa et al. 2004). Comanagement is one of the promising arrangements to address potential conflicts between multiple objectives such as biodiversity conservation, local economic needs, Indigenous rights, and equitable sharing of benefits (Borrini-Feyerabend et al. 2004). It can help transform conflicts into cooperation between government, Indigenous peoples and other stakeholders. Although difficult to set up, co-management holds promise to achieve management effectiveness, some degree of equitability in decision-making, and shared responsibility. It can also improve legitimacy by incorporating local knowledge into management (Borrini-Feyerabend et al. 2004; Mabee and Hoberg 2006; Singleton 2000). There is no single definition of co-management, as it encompasses a spectrum of power-sharing arrangements (Plummer and Fitzgibbon 2004). A basic definition is the sharing of

1 Natural Resources Institute, University of Manitoba, Winnipeg, R3T 2N2, Canada

* Corresponding author. E-mail adresses: JP (julia.premauer@gmail.com),FB (fikret.berkes@umanitoba.ca)

2 Natural Resources Institute, University of Manitoba, Winnipeg, R3T 2N2, Canada 
power and responsibility between the government and local resource users, involving some kind of formal arrangement (Berkes 2010).

However, there are many challenges to crosscultural co-management involving Indigenous peoples, and equity outcomes have been mixed (Borrini-Feyerabend et al. 2004). One major critique of co-management is the tendency of governments to keep hold of power by various means, instead of sharing it, leading Indigenous peoples into disadvantageous positions (Nadasdy 2005; Stevenson 2006). In drawing lessons, it is important to examine carefully the nature of a particular co-management arrangement, and how conflicts and other problems are handled.

This paper uses co-management thinking to understand and describe a collaborative management process in Makuira National Park, Colombia, between the national parks authority (hereafter, Parques Nacionales) and independent Wayúu Indigenous governing authorities. Makuira National Park (hereafter, the Park) is entirely within an Indigenous collective territory (Spanish resguardo) recognised by the Government. This collaboration experiment in PA governance encompasses various formal objectives: biological, territorial and cultural protection, joint natural resource management, and recognition of Indigenous governing authorities. The distinctive elements of this case are the strategic collaboration between Parks and Indigenous peoples to pursue a strong shared interest: territorial protection against external threats and collaboration for enhanced land governance.

The kind of collaboration in the present case is not about management but more fundamentally about governance. Governance is about who makes decisions, who holds power, authority and responsibility, and who is (or should be) held accountable. By contrast, management concerns plans, activities and resources to reach established objectives (Lockwood 2010; Borrini-Feyerabend et al. 2012). Parques Nacionales makes a distinction between governance and management, and labels the collaborative governance arrangement in Makuira, literally translated from the Spanish cogobierno, as "co-government". Co-governance is pursued with Indigenous governing authorities in titled territories overlapping with PAs, recognising Indigenous peoples' self-governing rights and responsibilities. By contrast, co-management is established with any other stakeholders and rights-holders that live inside PAs but have not been granted self-governing rights.

\section{Co-management and Indigenous peoples}

Co-management in PAs with Indigenous peoples is framed by the IUCN with an eye towards conservation as co-management should enhance conservation through both compliance to agreed-upon rules and the exercise of conservation responsibilities by communities (Borrini-Feyerabend et al. 2004). The literature does not always distinguish between kinds of rights, often framing Indigenous peoples as just stakeholders. The kinds of power-sharing are also important, in that increased sharing of power over decision-making processes should better align decisions with local realities and needs (Mabee and Hoberg 2006; Singleton 2000). Conflict will never be completely eliminated, but the potential of restructuring established relationships may open possibilities for new forms of constructive engagement (Singleton 2000).

Co-management describes a range of relationships (Pomeroy and Berkes 1997); for the critics, co-management is often a subtle way for governments to remain in control of decisionmaking (Nadasdy 1999). In many cases, the state holds control over the definition of management objectives, procedures, and most final decisions, reducing collaboration to advice (Howitt 2001). Power inequality in co-management is a persistent problem (Ross et al. 2011). One major barrier leading to Indigenous disempowerment in cross-cultural co-management is the epistemological challenge of achieving an equal dialogue between science and Indigenous ways of knowing (Nadasdy 1999; Stevenson 2006). A second barrier is the structural challenge of dealing with bureaucratic pre-exiting contexts that effectively marginalise Indigenous peoples' voices in management (Mabee and Hoberg 2006; Nadasdy 2005; Ross et al. 2011). Comanagement often treats "community" as one homogeneous group and fails to take into account 
the internal ethnic, class or other divisions and interests inside the communities, missing a layer of social complexity in conservation management (Agrawal and Gibson 1999).

However, there are also documented cases where co-management has positively redefined power relations between the state and Indigenous Peoples (Kofinas 2005; Singleton 2000; Spaeder 2005). Government agencies are not monolithic; power is not always exercised uniformly in local contexts (Robbins 2004). Local political processes and larger historical and geographical contexts account for such differences in outcome (Spaeder and Feit 2005). Recognition of rights to autonomy, self-determination, and rights to territory are fundamental for successful co-management with Indigenous peoples (Weitzner and Manseau 2001). With attention to the hidden asymmetries that reproduce power imbalances between governments and Indigenous peoples, critics point to the need for co-management regimes to address issues of plurality and respect, and recognise the autonomy and authority of Indigenous partners (Spaeder and Feit 2005; Stevenson, 2006; Weitzner and Manseau 2001). Understanding the broader socio-political context of Indigenous rights struggles is also necessary to analyse the circumstances under which co-management is working and why (Brockington et al. 2008).

The objective of the present paper is to analyse the co-governance process as a crosscultural relationship in terms of how compromises and trade-offs are being dealt with. We argue that the existence of recognised common interests, despite differences in motivation, as well as compromises and trade-offs, provide the basis for sustained collaboration in PA governance. We assume that conservation is a complex problem that defies blueprint approaches, and hence the context of each case has to be taken into account (Berkes 2007). We analyse how the case deals with multiple objectives and how it uses deliberation. In focusing on trade-offs, we contribute to the "new conservation debate" that addresses ethical pluralism in conservation as a social endeavour, and suggests working from the outset with tradeoff thinking rather than the often unrealistic winwin thinking (McShane et al. 2011). Much has been written about whether the inclusion of social objectives compromises conservation objectives (Berkes 2007). The governance approach taken in Makuira National Park may be relevant for understanding how to work with both.

Following a section on the biophysical setting of Makuira, we briefly describe Wayúu Indigenous people and their self-governance. After a section on study methods, results sections cover elements of Park co-governance and its cross-cultural challenges, to help understand the nature of the interaction of the two parties. The next two sections are about both common and conflicting interests of the two parties, considering the role of compromises as a necessary part of a pluralistic governance approach.

\section{Place, people and context for co-governance partnership}

The Guajira peninsula is located in the northeast part of Colombia. It is home and ancestral territory of the Wayúu people who were granted title over two-thirds of the peninsula $(1,067,505 \mathrm{ha})$ in 1984 as collective Indigenous property under the title of Great ResguardoWayúu of Middle and Upper Guajira (INCORA Resolución No. 0015, 28 de Febrero 1984). Many Indigenous peoples' territories in Colombia are fully recognised by the Government with the legal status of resguardo that grants collective land tenure to the claiming Indigenous group. Resguardos cover one-third of Colombia's national territory and more than 80 percent of the forested areas with high biodiversity values (Hammen 2003). In exercising self-determination, Indigenous peoples in Colombia hold the right to govern themselves regarding economic, social and cultural development inside the resguardo. Indigenous peoples' autonomy and self-determination does not mean complete sovereignty but a high degree of autonomy in internal affairs. The 1991 Constitution granted both resguardos and national parks the status of being outside of the market. This means the land cannot be sold, prescribed or confiscated (Article 63). However, while national parks protect subsoil minerals as well, in resguardo lands subsoil minerals can still be exploited as they belong to the state. 
The Makuira Mountains, located in the north of the peninsula, is a small mountain range of $30 \mathrm{~km}$ by $15 \mathrm{~km}$ with elevations up to $865 \mathrm{~m}$. Because of its dwarf cloud forest ecosystem growing at an unusually low altitude (below 1,000m) and almost completely reliant on horizontal precipitation (fog), Makuira National Park was established in 1977 and remained a paper park until the 1990s. The Park comprises 25,000 ha that are entirely within the Wayúu resguardo (Figure 1). This park-resguardo overlap is no surprise since national parks in Colombia were established without regard to Indigenous lands, leading to 29 of 54 national parks overlapping partially or completely with 53 de jure resguardos and 6 de facto indigenous territories (Riascos et al. 2008). The resulting widespread conflicts between
Indigenous peoples and parks authority became with time one of the main reasons for Parques Nacionales to diversify national park's governance to include some forms of shared governance. Thus in 19982000, Parques Nacionales developed the "Parks with People" policy for participatory conservation. Collaborative governance between parks authority and Indigenous peoples in overlapping areas of land is based on recognition of Indigenous rights, local governing authority, cross-cultural management practices, and conservation as management rather than preservation (Correa 2002). The policy, still in force as of 2013, has suffered through changes in government priorities that have weakened environment and Indigenous rights issues to give priority to the mining sector (Premauer 2013).

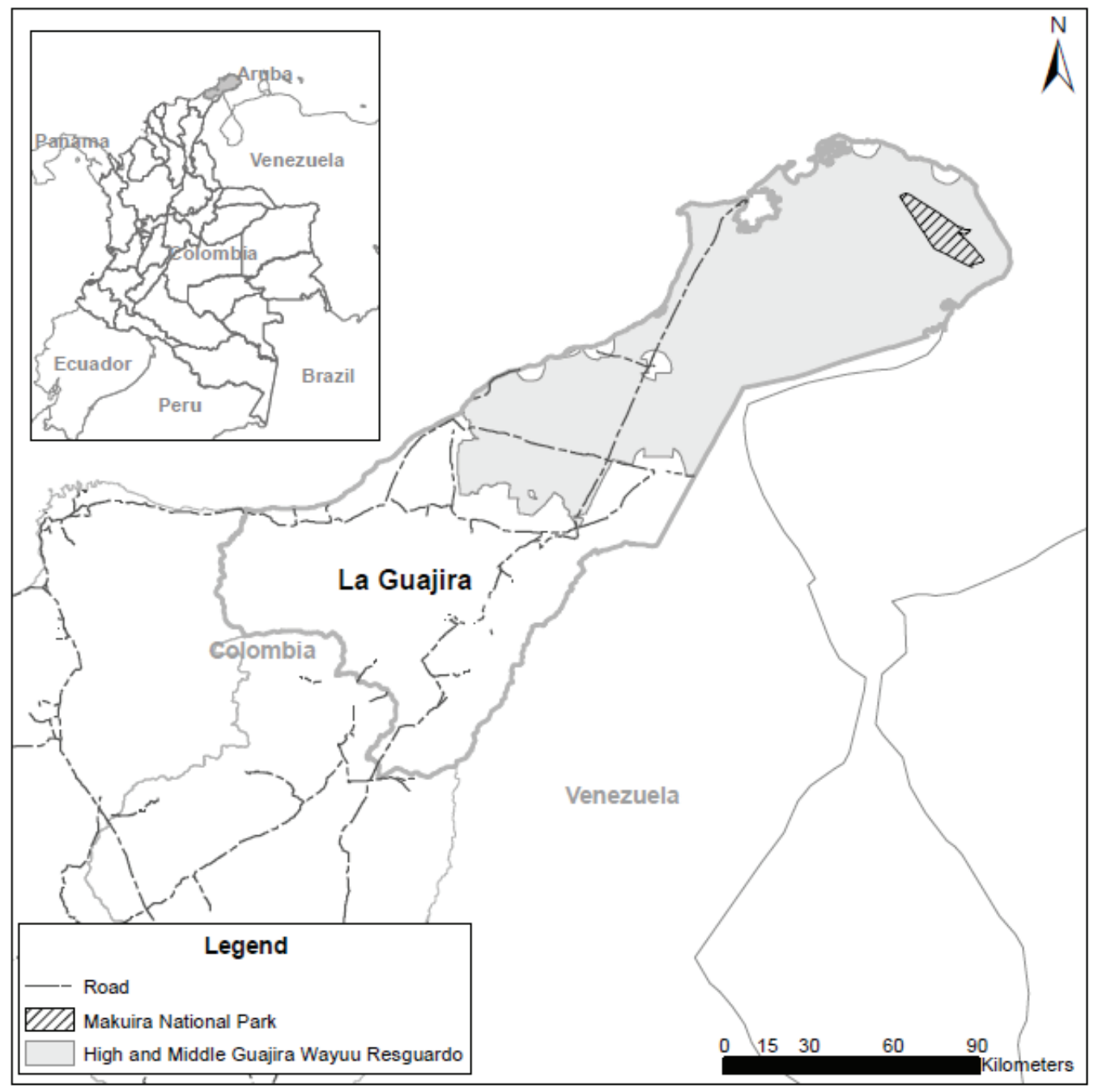

Figure 1. Location of the study area 
Makuira mountains are located in the Caribbean dry belt determining a dry scrubland vegetation; however, fog forming in the windward side of the mountains allows for several forest types to grow, including the dwarf cloud forest mentioned before (UAESPNN 2005). Significant plant and bird diversity with important endemism has been reported (UAESPNN 2005). Makuira's heterogeneous landscape has been shaped for centuries also by agriculture, grazing, and selective forest use. The Wayúu population in the Park was approximately 2,000 in 2006, living in dispersed settlements belonging to 54 Wayúu extended family territories (Park Manager 2, personal communication, August, 2009). Makuira National Park is no exception to the governance problems faced by PAs in Colombia. Governance capacity of Parques Nacionales is negatively affected by low economic resources, understaffing, and by illegal armed groups that threaten the governability of all areas (Durán 2009). In Makuira, illegal armed actors controlling drug trade corridors in the peninsula negatively affect both Wayúu autonomy and Parques Nacionales capacity to govern the PA. These are important themes but beyond the scope of this article. The co-governance process takes place against this background.

\section{Wayúu Self-Governance}

The Wayúu cultural and historical context on la Guajira peninsula has been one of continuous relation with outsiders through conflict, resistance and alliances that has signified cultural adaptation, trans-acculturation, assimilation and syncretism (Polo-Acuña 2005). With the Wayúu concept of anás (wellbeing), a good life means to be able to alternate between economic activities according to available opportunities; to be able to move between livestock keeping, trade, handcraft production, growing food and waged labour, among other activities. Wellbeing also means to be able to operate effectively in Wayúu society increasing the prestige of one's extended family by fulfilling the social obligations of compensation payments ${ }^{3}$ and redistribution both made mainly with livestock. Water allows for life

3 Compensations for wrongdoings in general and for supporting livestock which fulfil the social obligations. Prestige is also increased by good management of conflict (Ballesteros et al. 2001). In Makuira the availability of water allows for seasonal agriculture in fixed plots which is mainly for the household, while every extended family in the peninsula keeps goats and sheep.

Governance of the Makuira area has been, and remains, mostly Indigenous. Wayúu customary territorial governance is a complex system of beliefs, norms, and practices that regulate the relationships among the Wayúu and between the Wayúu and supernatural beings (Correa 2005). For the purpose of this paper, we will briefly refer to some important elements of Wayúu governance on common lands (the Wayúu way of sustainable use of natural resources) to understand their interaction with the Park (Premauer 2013). Wayúu commons governance elements are: (1) a system of customary land ownership under family chiefs with monitoring and control of access to territory, and (2) sacred, taboo places with rules-in-use to deal with supernatural beings.

The Wayúu organise their collective land in politically autonomous extended-family territories or Wayúu homelands. Collective ownership is proven by signs of ancestry (i.e. places of mythic origin, family cemeteries, certain trees, and cultivation plots). Ownership determines norms that determine rights of access, use and exclusion of the natural resources contained in a Wayúu homeland, leading to the Wayúu way of sustainable use. Examples of these norms are: ask for permission to enter the land, cut a tree, or graze their goats; take only what you need; practice reciprocity with the land owner; when needed, obtain temporary access through land loan. Hence, Wayúu vision and practice of conservation is mainly about social relationships and thus different from its Western counterpart.

Most Wayúu homelands have a young bilingual community leader and the head of family in charge, respectfully called "My Uncle", who is usually a monolingual older male on the mother's side of the lineage. The Uncle is the knowledge-holder of that territory: he knows its boundaries, oral history, and the lineages of every inhabitant. $\mathrm{He}$ is in charge of cemeteries and 
natural resources, solves minor conflicts, controls access of strangers, gives advice when people do not behave according to the Wayúu customary law, and makes decisions regarding the land and social issues in consensus with his family. The Wayúu do not have a centralised organisation that represents their vision and interests collectively as a people; thus, negotiations in the Park are carried out with individual extended family chiefs. While there is a customary system in place for monitoring trespassers in their homelands, there are problems with enforcement and compliance. Problems include Government economic development interests, illegal actors, and the lack of respect of Wayúu younger generations towards the customary practices of older generations.

Sacred sites in the Wayúu land management system are functionally similar to conservation, although based on a fundamentally different motivation (Premauer and Berkes 2012). Makuira Mountains are the Wayúu mythological place of origin; thus, for them it is sacred as a whole. It has numerous culturally protected sacred, dangerous, and enchanted taboo places: cloud forests, mountains peaks, springs and creeks, rocks and burial grounds that require strict codes of conduct to show respect and avoid harm from supernatural beings. Access to such sites is regulated by directions given in dreams and taboos. Wayúu "conservation" is about maintaining respectful relationships with supernatural beings in their abodes in the landscape. Acknowledgement of legitimate Wayúu chiefs, their land ownership, customary institutions for territorial governance and resources use including sacred places are key elements taken into account by Parques Nacionales for collaboration in the management tasks of the Park.

\section{METHODS}

A study of relationships between Indigenous peoples and PAs should consider not only formal but also informal aspects of the relationship, and the broader contexts in which it is situated. Thus, we inquired about the history of Parks-Wayúu relationship and investigated how the day-to-day informal collaboration worked, and the issues of encounter and disagreement. Field research followed a qualitative ethnographic approach. Fieldwork and interviews (2009 and 2010) took place at the Park and Bogotá. Data collection was based on 15 semi-structured and informal interviews including the Park's past and present managers and staff in Bogotá ( $n=3$ individuals), Wayúu Park staff $(n=5)$, and Wayúu community members $(n=7)$. Existing qualitative data collected by the Park staff (25 interview transcripts with Wayúu chiefs) were also used. Examples of key guiding questions for interviews and themes extracted from the transcripts were: What are Wayúu concerns about territory and resources? How are the regional contexts influencing the institutions governability and autonomy? How do Wayúu see their relationship with the Park? What does collaboration between Parks and Wayúu authorities look like on a day-to-day basis in Makuira National Park? What are the points of agreement and disagreement between Wayúu and Parks? The quotes used in this paper are representative of responses provided.

In addition to the interviews, document management reports, evaluations, planning exercises, correspondence, and minutes were reviewed and analysed. Participant observation was carried out at Park internal meetings, meetings with Wayúu authorities, day-to-day management activities, and everyday life of a Wayúu family that provides local accommodation for tourists. Data analysed covers the period, 2004 to 2010. Data analysis process was done throughout field work, following Creswell's (2007) description of loops used in case study analysis. Validity was ensured with triangulation of information using multiple data sources and attention to context during fieldwork. More details of the study methods may be found in Premauer (2013).

\section{RESULTS}

\section{Nature of Park co-governance}

As required by Parques Nacionales, all parks with overlapping jurisdictions with resguardo must set up co-governance arrangements and a joint 
Park management plan (REM agreement). When asked for their understanding of REM, Parques Nacionales staff at the headquarters in Bogotá had different views than Makuira PA staff of it. At the headquarters, co-governance and REM is reduced to an end goal: the signature of REM agreements. "The Government strategic plan is to sign 13 REM by 2010 [...] so far, we have only signed 4. [...] this is why so much effort is put into signing the agreements" (staff at headquarters, interview, August 17, 2010). For the Park staff, co-governance is an ongoing informal process side by side with the development of formal REM agreements. Informal co-governance involves maintaining respectful relations and ongoing problem solving that require joint decisions. Thus, we found tensions on the need to rush a process that has its own pace as Park manager 2 explained:

At the headquarters the question is: when do we sign, when do we sign, when do we sign? They do not see the process: how it is working out, what is needed for an effective process. Participation Office pushes too hard and maybe there are things that could be designed better, discussed better, negotiated better, which require their own times. [...] National priorities are above local priorities, this is how it works, one understands (interview, May 4, 2009).

Implementation of participation policy and cogovernance began in 2004 as explained by Park manager 2: "Parques Nacionales issues general guidelines for parks overlapping with resguardos. At the local level, it is decided how to go about developing the REM, according to local social and cultural contexts" (interview, May 4, 2009). The Park idea was as much about respecting Wayúu rights, as about improving the Park's governance. The Park needed three years of research and building local relationships to learn about Wayúu social, political organisation, territorial management practices, and to identify the legitimate governing authorities. In 2006, Wayúu chiefs agreed to work jointly with the Park. While most chiefs found it positive to work collaboratively, others remained reluctant to deal with the Park's presence in their territories. Most Wayúu accepted to collaborate with the Park because of the respectful relationship they had with the Park manager, as pointed out by a Wayúu Park staff (interview, June 5, 2009). For the Wayúu, REM is an alliance, a relationship that provides certain benefits such as back up for protecting their territory.

As part of a joint decision-making strategy, a so-called "wise men council" was created composed of 54 Wayúu chiefs of independent customary family territories and the Park manager. The strategy consisted of four meetings conducted on consecutive days, each covering a quarter of the Park area. This enabled meeting Wayúu authorities as close as possible to their own territories to spare them long distance travel. It also meant having smaller groups of approximately 13 authorities at a time, and preventing enemy clans from meeting, with possible violent outcomes. Meetings were held entirely in Wayúu language and translated by the bilingual Wayúu Park staff. This participation format proved to be useful and appropriate, and as of 2013 was still in use. The first joint decisions were about the Park's conservation objectives involving both biodiversity and culture. Biodiversity objectives included protection of mountain peaks, the dwarf cloud forest, and hydrologic resources. Cultural objectives included the protection of Wayúu territorial rights (UAESPNN, 2005).

\section{Cross-Cultural Challenges}

\section{Expectations of co-governance relationship}

The Wayúu are pragmatic people and expect practical outcomes to perceived problems out of entering into a relationship with non-Wayúu like the Park manager. The expectation of reciprocity is part of their cultural norms; they expect to be reciprocated in the same way at another time, just as they have done historically when interacting with non-Wayúu. Wayúu approach most of their interactions with non-Wayúu as transactions (i.e. agreements involving the exchange of items of value) (C. Puerta, interview, August 18, 2011). The practical outcomes work regarding protection of territory, respect of Wayúu ownership of territory and strengthening of their Indigenous governing authority (see Section on common interests). However, there are other examples of tangible 
activities that contribute to the relationship such as: capacity building for garbage disposal, mediation in territorial conflicts between families inside the Park area, activities for cultural revival. Such actions are not the core of, co-governance but none the less they are complementary concrete actions that also contribute to build their relationship. The amount and efficiency of the Park in doing these depends on the leadership of the Park manager. Parques Nacionales has a reduced budget. This leads most of the time to a relationship with local people based on a conservation rhetoric and accomplishment of administrative requirements. Thus, most practical solutions to issues depend on any Park manager's willingness and capacity to mobilise resources for projects. In Makuira, Park manager 2 achieved to show the Wayúu through concrete actions what Parques Nacionales could give them. However, achieving complemetary concrete outcomes was no longer a priority with the next manager.

\section{Practices for decision-making}

Wayúu society is not organised under a set of centralised representative bodies. Makuira Mountains have 54 chiefs. The Wayúu chief is the spokesperson for his extended family group's interests. However, he is not representing them with the authority to make decisions on his own. He normally discusses the decisions back with the older uncles and aunts in his family to reach a consensus; besides of seeking advice in dreams. In contrast, Parques Nacionales collaboration is based on a system of representation and delegation. Following the case-by-case co-governance implementation principle, Makuira Park acknowledged and included all of the 54 authorities in meetings and negotiations. However, constraints of time and money resulted in a kind of participation based on discussing issues and reaching consensus in meetings, without the extra time that allows for consulting with extended families. This challenge was acknowledged several times by the Park manager 2 (interview, May 4, 2009).

\section{Cross-Cultural Dialogue}

Dealing with different languages provides a challenge when translation, the lynch-pin of communication in a multi-lingual context, is not given the importance and time that it requires. Translation in a cross-cultural context is always linked to explaining concepts from another worldview, and the Wayúu staff well-understand the difficulties of such a task. Park meetings occur mainly in Wayúu language, which means that Wayúu authorities are empowered to speak freely. However, themes are prepared in Spanish and there is little time for the staff to discuss the meaning of themes and prepare appropriate translations prior to meetings. This may lead to misunderstanding by Wayúu authorities and to mistrust by Parks' staffs who do not speak the language.

\section{Common interests, different motivations}

Participation policy has allowed joint Park planning, an informal reciprocal relationship, and a collaborative problem-solving practice, based on the interests and needs of both local Park management and the Wayúu. Three key common interests between the Park and the Wayúu are: (1) protection of territory, (2) strengthening of Indigenous governing authorities, and (3) controlling access to taboo areas (Table 1). These common interests underpin the collaborative governance relationship. Table 1 shows that, in spite of different motivations behind the common interests, awareness of both sides about their own limitations results in finding a benefit from having each other as partners.

Protection of territory against external threats is the first and most outstanding common interest. In the following example regarding mineral prospecting referred to in interviews and documented in the Park's archive, the Park supported the Wayúu in the protection of their territory and their right to a prior informed consent without co-optation. In 2007, at the height of the rush for opening the country to mining capitals, the Government ordered a mineral prospection of the whole Guajira peninsula, including the Makuira Mountains. Parques Nacionales as a government institution had to comply and allow the explorations. However, the Wayúu had to be asked for their prior informed consent before the explorations began. The Park actions served as 
a link that ensured proper consultation with the Wayúu, something that is seldom the case. It was a cornerstone for building trust for the relationship of co-governance in the Park area.

The Park ensured the Wayúu got the project information prior to the meetings, those attending the meetings were the Wayúu chiefs and not someone who was paid for being there, and a proper translation to the monolingual chiefs during meetings. The Wayúu at the meeting expressed their contentment for the respect shown to them as owners of the land. The answer of most Wayúu chiefs was negative. Thus, the mineral and oil prospection activities did not take place in Makuira. This course of action privileged Wayúu rights to autonomy and benefited the Parks-Wayúu relationship. It granted power to the Wayúu to decide what they wanted to see happening in their territories despite the Park having the obligation to allow the prospection activities. By showing such respect, the relationship between the Park and the Wayúu was strengthened. To have parks officials in line with Wayúu territorial interests provides them with an important ally within the State, which is otherwise almost absent. In cases of external threats and non-compliance, the Park has supported Wayúu authorities. The relationship with the Park has facilitated the creation of vertical linkages between local and national Government institutions, linkages that would not otherwise be there.

A second related interest is the recognition and respect of Wayúu ownership of territory and strengthening of their Indigenous governing authority. For conservation reasons, the Park is interested in an increased governance capacity in partnership with the Wayúu to control access to the Park area. The Park is understaffed to control access by intruders. This requires collaboration with the Wayúu, who are "on the ground", to monitor activities of outsiders and legitimises Wayúu authority and customary territorial arrangements. The Wayúu are interested in controlling nonWayúu outsiders with the Park's backup, and be respected as owners of their homelands. In cases of dealing with non-compliance to agreed rules with regards to environmental issues, the Wayúu let the Park staff know whenever they need backup. On the other hand, if the Park manager learns that outsiders are cutting trees, for instance, she would take a joint decision with the chief of that Wayúu territory on how to proceed. 
Table 1. Common interests between Makuira National Park and Indigenous peoples

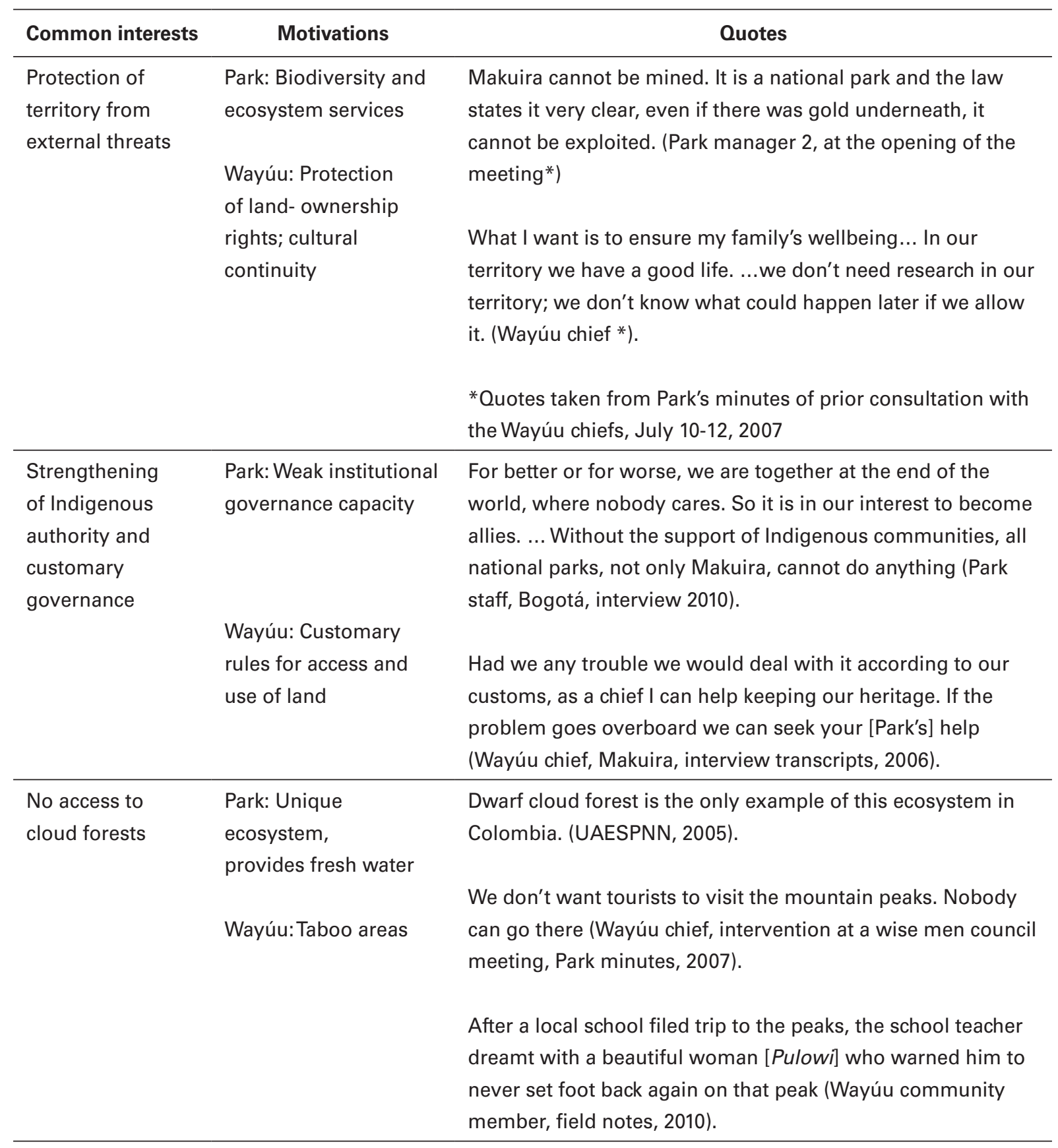

The third common interest is to restrict access to mountain tops with cloud forests.

The Park planning process incorporated inhabited and sacred places of Makuira building upon Wayúu worldview and appropriation of the landscape. The Park and Wayúu chiefs have agreed, for entirely different reasons, that the mountain peaks are "no go" areas for tourists, and are only customarily used on special occasions when so directed by dreams. The quotes in Table 1 show Park's interest is conservation of biodiversity and aquifer recharge areas of fresh water streams in northern Guajira. In contrast, the Wayúu interest is to avoid people from getting harmed as cloud forests are dangerous places known to have supernatural beings: Pulowi (hyper-feminine being) or Wanetunai (man with one leg). The helicopter story, quoted below, is a widespread warning 
story, with many versions. In some versions it is Pulowi who appears as a beautiful woman who offers researchers enchanted food that kills them, in others it is Wanetunai who asks for food and after not receiving anything makes them fatally ill.

\begin{abstract}
"My father told me that a long time ago anthropologists came to study the mountains; they arrived by helicopter up to the Paluou peak. They built a shelter up there and the next day Wanetunai made his appearance. He did not speak; he only opened his hand asking for food. The researchers cut the air with a machete as they tried to hurt him and Wanetunai disappeared. They had just enough food for breakfast, for lunch, just enough. The researchers did not want to give food to Wanetunai. The next day Wanetunai appeared again, opening his hand. The researchers were angry yelling at him: "What is wrong with this wild animal?" After three days they got very sick and started to die one by one. The ones who managed to leave alive, in their helicopter, died later at home" (Wayúu interviewee, June 12, 2009).
\end{abstract}

Common interests serve both to achieve a more effective governance of the Park area and help building trust, respect and reciprocity all of them key to the cross-cultural relationship that this co-governance arrangement is about. However, there are also areas of disagreement especially with tourism.

\section{Conflicting interests and trade-offs}

The main conflicts between the Wayúu and the Park are summarised in Table 2. Makuira National Park has small-scale tourism, involving local guides trained by the Park, five Wayúu households in the village of Nazareth that provide accommodation close to the Park area. Over the years, each of these families has developed relationships and loyalties to tourist operators in the cities of Riohacha and Bogotá. Makuira National Park tourist attractions are located inside different Wayúu homelands. However, tourist access to Wayúu homelands is an issue that the Park did not negotiate with the Wayúu chiefs, as it is a given for any protected area that tourism should be part of it. The Wayúu are not entirely happy with this.

Wayúu chiefs from territories with tourist attractions were very vocal about their expectations and concerns with tourism back in 2004. They required that tourists show respect to them as owners of the land, as they hold distrust in nonWayúu people as the following quotes show: "Our land is divided in family ownerships.... nobody should enter without permission. They can visit our land with a local Wayúu guide, non-Wayúu must not come by themselves, we don't know what their intentions might be...you cannot trust them, they are very violent." Wayúu chiefs' expectations also included getting economic benefits from accommodation and crafts selling: "Visitors should stay overnight inside the mountains, not just in Nazareth. We want their visit to be of benefit to our people. We have to show them the crafts our women do: bags and hammocks." But there is also an expectation for reciprocity as the following quotes show: "They are welcome [...] to help us with solutions for the plants that are killing our animals...They must know better because they have studied."

Based on Wayúu recommendations the Park trained a group of local guides and required tourist groups to attend a short talk about the biological and cultural aspects of the Park as well as the respect they have to show. Things changed when in 2007 visitors numbers increased three-fold as compared to 2004 (from 299 to 910 visitors per year). The two central components of conflicts involving tourism were again economic benefits and visitors' control. The Wayúu chiefs from the two territories with the most visited tourist attraction (a waterfall) called the Park manager to a meeting to discuss disrespectful behaviour of tourists and car drivers, and the burden of dealing with them, with no economic benefits. Some Wayúu said tourists were "worse than goats" as they made lots of paths everywhere they walked. Speeding cars caused road accidents with livestock. Wayúu people did not like tourists getting drunk, smoking marihuana, or seeing female tourist walking around in "underwear" (i.e. wearing bikini).

The Park manager and the Wayúu came to agree to take actions for visitor control. The Park agreed to put signs at the dirt roads ("No vehicles allowed in the Park"), to inform tourist operators about not having vehicles in the Park, and to train guides specifically from those two territories to take the tourists around and explain them 
respectful behaviour. The Wayúu agreed to start building a community-managed accommodation for tourists in their territory, build rest stops with latrines, and sell handcrafts.

Table 2. Conflicting interests between Makuira National Park and Wayúu. Statements are by the Wayúu chiefs and Park staff.

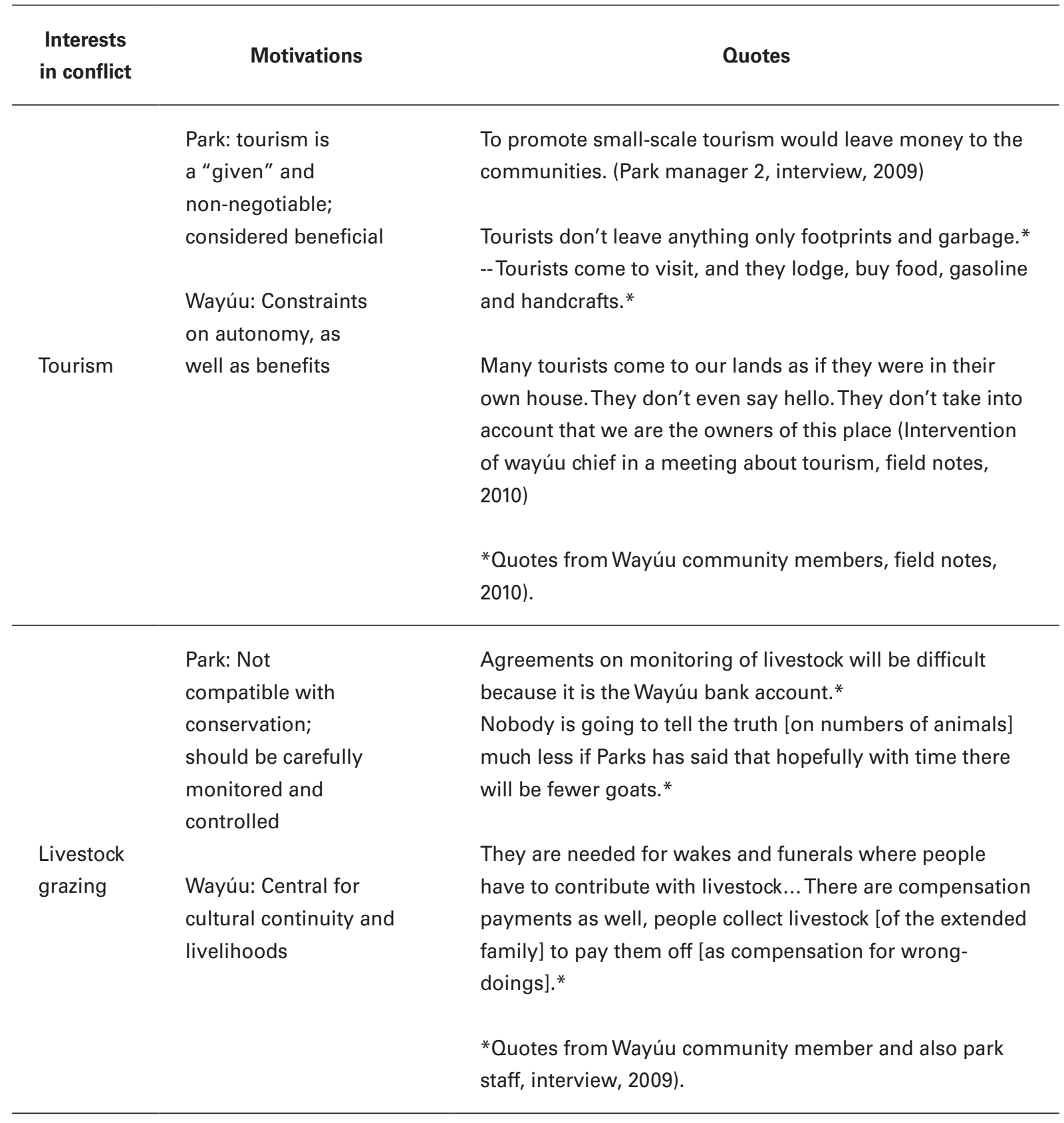

However, on the Park side, these measures proved insufficient, in part because not every tourist operator respected the instructions from the Park, tourist guides abused the rules, and the "no entrance" signs for vehicles were soon vandalised. On the Wayúu side, the house for tourist accommodation was built but was never used, as no one took responsibility for the project, which is part of the intrinsic difficulty of the Wayúu to work in collective projects. Opinions were divided between those who were in favour of tourism and those who did not want to see tourists 
in their territories. The Park decided not to charge an entrance fee, since the collected monies would be centrally redistributed for all national parks, leaving no chance to share it with the Wayúu.

In sum, problems arising out of tourism management illustrate some of the constraints of Wayúu governance. Parques Nacionales interests and priorities dominate with tourism considered non-negotiable. The Park responded to a number of Wayúu concerns; however, the possibility of not allowing tourism altogether was not considered. The Wayúu were keen to receive economic benefits from tourism; however, community members had mixed feelings towards tourism and a low capacity to work as a community in a collective project.

The second area of disagreement among the parties concerns the issue of livestock. This is worth mentioning as an issue where the Park has to compromise their conservation ideals; however, an assessment of cattle impacts in the Park area was out of the scope of this study. Park census in 2006 showed an average of two corrals per household. In Wayúu society livestock is directly connected with wealth, prestige, and the ability to function in the society by paying compensation payments for offences, matrimonial alliances, and for ceremonies such as burials and wakes. As put by one of the Wayúu authorities, livestock is their "walking savings account". But it is much more than that: it has symbolic attributions of being of the same flesh of the family owning them. Livestock is non-negotiable for the Wayúu. For the Park manager, livestock grazing is not compatible with conservation. In an ideal scenario livestock should be carefully controlled or even banned. However, in actual negotiations with the Wayúu, Parks decided not to press the issue (for the time being), and only discussed that no livestock should go to mountaintops. Nothing further was discussed; thus, Parks were compromising and accepting livestock (and horticultural plots) in the Park management zone where people live. In terms of trade-offs the Wayúu compromise the exercise of their full rights of self-determination, as economic rights are dependent upon conservation objectives and tourism, and are thus constrained by the presence of the Park in their territories. Conversely, the Park compromises on their conservation ideals.
The REM agreements signed in 2011 constitute a joint Wayúu-Parks management plan based on four management themes: sacred areas, sustainable resource use, permanent social use, and tourism, with their respective sets of rules jointly agreed upon. REM objectives were described in terms of territorial ordering, use of natural resources, conservation of biodiversity, and Wayúu ancestral territory and culture. Indigenous autonomy and self-government were included throughout the text of the document, as well as a constant cogovernance with the Park authority, for actions and decisions regarding environmental matters. "Joint management will respect Wayúu customary law and the legal competences of the environmental authority therefore lack of compliance to this agreement will be handled in the first place using the customary 'advice giving' of Wayúu authorities and the Park will only intervene in environmental matters".

\section{DISCUSSION AND CONCLUSIONS}

Co-governance in Makuira National Park provides insight on the importance of acknowledging the social realities and everyday interactions of protected area management. Our results agree in that successful conservation needs pluralistic approaches that integrate tradeoffs and compromises into the management and assessment equation (Berkes 2007, McShane et al. 2011, Brechin et al. 2010). First, co-governance in Makuira incorporates compromises and trade-offs for the two involved parties regarding conservation ideals and self-development rights. Second, plurality means the Park management respects territorial and cultural rights; and works with governance, not just management. Cogovernance builds on local indigenous institutions, acknowledging chiefs, and focuses on shared interests for land protection despite different motivations.

Dealing with multiple objectives, such as biodiversity conservation and Indigenous peoples' rights involves trade-offs in which "some things are gained while others lost", which if acknowledged, are believed to lead to "sustainable and resilient" 
results (McShane et al. 2011, p.969). The Wayúu have compromised full recognition of their economic and self-government rights. For example, they have no say over banning tourism, but they can say how they want to see tourism managed on the land and the Park makes an effort to attend to their requests, but not always with success. Given that the area in which the Park is located is also titled to the Wayúu, the Park has compromised their ideals of biodiversity conservation; it has to allow land uses within its area that would normally be deemed unacceptable, including cultivating vegetable plots, harvesting trees for household needs, and cattle grazing. But dealing with trade-offs is not conflict free. Every now and then conflict arises when one party pushes the boundaries of their agreements in detriment of the interests of the other. For example, Park staff know that one particular family is making wood charcoal for sale, which is clearly not allowed in the Park; however, the family argues that their livelihood depends this economic activity. No one knew for sure their economic situation but they push the boundaries until the Park investigates further or other solutions are found. A co-governance that works and deals with compromises is not static, "success [...] is a condition of social process and dynamics" (Brechin et al. 2010).

Other cross-cultural challenges associated with this co-governance arrangement are the widespread disempowering effects of Indigenous partners due to conflicting worldviews and preexisting administrative contexts (Howitt 2001; Nadasdy 2005). The Park governance structure for decision-making has tried to accommodate the decentralised governance system of the Wayúu, but two major problems still linger. First, Wayúu chiefs are spokespersons, and not representatives, of their families. Thus, there are times when issues are discussed and decisions taken, power balance often shifts to the Park, as there is not enough time for chiefs to reach a consensus with the extended family in the Wayúu way. Parques Nacionales has deadlines to meet and its own administrative institutional times. Two different time-spans for decision-making may resonate with Blaser (2009) where the problem lies not in there being different epistemologies, but different ontologies at play, and the Park establishes a hierarchical relationship with the Wayúu. Second, the problem of representation also has drawbacks for the ability of the Wayúu to interact as equals with the Park in issues that require self-organisation beyond the family level. As there is no regional level organization, there is no unified Wayúu voice to negotiate with the Park. This diminishes the Wayúu ability to take advantage of economic benefits coming from tourism or other enterprises. This finding is consistent with that of Cronkleton et al. (2011) in the context of REDD+, where lack of institutions for representation of local communities at higher governance levels in Bolivia and Brazil was a serious governance weakness for the projects. Despite such challenges a strategic alliance between them works.

Effective conservationists-Indigenous collaboration occurs under a variety of conditions worldwide (Brockington et al. 2008). Indeed Tsing (2004) points out that it occurs in such settings where the parties in the relationship use global circulating ideas of biodiversity, human rights and equality to collaborate towards a common goal. Co-governance in Makuira is a further example of strategic collaboration for the common interest of land protection. Here we have an example of a type of alliance between Indigenous peoples and conservationists commonly found in Latin America that fights against external threats (Brockington et al. 2008, Schwartzman and Zimmerman 2005, Mason et al. 2010). This case works because of legal acknowledgment of territorial and self-governing rights. However, this condition is not found in other strategic alliances for co-management where the collaborative problem solving and indigenous-park relationships develop in the absence of government recognition of indigenous rights (Pinel and Pecos 2012).

The Makuira case shows that ParksIndigenous partnerships can work. Makuira is far from being conflict-free, but it provides lessons for conservation governance. Co-governance is based on a relationship that focuses on common interests, and it includes a search for respect and equity in decision-making. Indigenous rights and conservation interests are negotiated continuously and the resulting learning is incorporated into management, in effect, adaptive co-governance 
(Armitage et al. 2009). Ungar and Strand (2012), found in another Colombian PA, that adaptive co-management was not incorporated into the planning and management cycle as such, but was nevertheless useful in the social mobilisation of local capacity for park governance. In the Makuira case, the resulting territorial planning allows for both conflict management and protected area management. The integrity of this co-governance system is threatened by armed actors in the drug trade and by mining interests. During the fieldwork phase the system was able to control these external pressures through the complementary strengths of the two parties: the Indigenous people are "on the ground" at all times and the Park provides legitimacy for their self-governance.

\section{ACKNOWLEDGEMENTS}

We would like to thank staff at Parques Nacionales, Makuira National Park and Wayúu community members for their participation in the research. This study was funded through the International Development Research Centre (IDRC) Doctoral Research Award. Premauer was supported by a University of Manitoba Graduate Fellowship and Canada Research Chair in Community-based Resource Management (http:// www.chairs.gc.ca).

\section{REFERENCES}

1. Agrawal A, Gibson CC (1999) Enchantment and disenchantment: the role of community in natural resource conservation. World development 27(4):629-649

2. Armitage DR, Plummer R, Berkes F, Arthur RI, Charles AT, Davidson-Hunt IJ, Wollenberg EK (2009) Adaptive comanagement for social-ecological complexity. Frontiers in Ecology and the Environment 7(2):95-102

3. Bawa KS, Seidler R, Raven, PH (2004) Reconciling Conservation Paradigms. Conservation Biology 18(4):859-860

4. Ballesteros F, Navarro G, Passo E. (2001) ANAA AKUA'IPA. EI concepto de desarrollo In la comunidad wayúu del resguardo RIZZIA de las Delicias. Unpublished Thesis. Universidad de la Guajira: Riohacha.

5. Berkes $F(2007)$ Community-based conservation in a globalized world. Proceedings of the National Academy of Sciences 104(39):15188-15193

6. Berkes, $F(2010)$ Devolution of environment and resources governance: trends and future. Environmental Conservation 37(04):489-500
7. Blaser M (2009) The threat of the Yrmo: The political ontology of a sustainable hunting program. American Anthropologist 111(1):10-20

8. Borrini-Feyerabend G, Kothari A, Oviedo G (2004) Indigenous and Local Communities and Protected Areas: Towards Equity and Enhanced Conservation. Cambridge, UK: IUCN and Cardiff University.

9. Borrini-Feyerabend G, Dudley N, Jaeger T, Lassen B, Broome NP, Phillips A (2012) Governance of Protected Areas: from understanding to Action. Best Practice Protected Area Guidelines Series No. 20, UICN, Gland, Switzerland

10. Brechin SR, Wilshusen PR, Fortwangler CL, West PC (2002) Beyond the Square Wheel: Toward a More Comprehensive Understanding of Biodiversity Conservation as Social and Political Process. Society \& Natural Resources 15(1):41-64

11. Brechin SR, Murray G, Mogelgaard K (2010) Conceptual and practical issues in defining protected area success: The political, social, and ecological in an organized world. Journal of sustainable forestry 29(2-4):362-389

12. Brockington D, Duffy $R$, Igoe J (2008) Nature unbound: conservation, capitalism and the future of protected areas. Earthscan, London

13. Correa HD (2002) La construcción de la política de participación social con los pueblos indígenas en la conservación de las áreas protegidas. In: UAESPNN (ed) Parques con la Gente II. Avances 2000-2001. UAESPNN, Bogotá, pp.105-128

14. Correa HD (2005) Cuando la sal se corrompe. Wayúu, Estado y empresarios en las salinas de Manaure 1970-2004. CEREC, Akuaipa Waimakat, Cultura Hispánica, Bogotá

15. Cronkleton P, Bray DB, Medina G (2011) Community Forest Management and the Emergence of Multi-Scale Governance Institutions: Lessons for REDD+ Development from Mexico, Brazil and Bolivia. Forests 2(4):451-473

16. Durán CA (2009) Gobernanza en los Parques Nacionales Naturales colombianos: reflexiones a partir del caso de la comunidad Orika y su participación en la conservación del Parque Nacional Natural Corales del Rosario y San Bernardo. Revista de Estudios Sociales 32:60-73

17. Hammen MC van der (2003) The Indigenous Resguardos of Colombia: their contribution to conservation and sustainable forest use. 1ed.Guiana Shield Initiative of the Netherlands Committee for IUCN, Amsterdam

18. Howitt R (2001) Rethinking Resource Management: Justice Sustainability and Indigenous Peoples. Routledge, New York

19. Kofinas GP (2005) Caribou Hunters and Researchers at the Comanagement Interface: Emergent Dilemmas and the Dynamics of Legitimacy in Power Sharing. Anthropologica 47(2):179-196

20. Lockwood M (2010) Good governance for terrestrial protected areas: A framework, principles and performance outcomes. Journal of environmental management 91(3):754-766

21. Mabee HS, Hoberg G (2006) Equal Partners? Assessing Comanagement of Forest Resources in Clayoquot Sound. Society \& Natural Resources 19(10):875-888

22. Mason D, Baudoin M, Kammerbauer H, Lehm Z (2010) Comanagement of National Protected Areas: Lessons Learned From Bolivia. Journal of Sustainable Forestry 29(2-4):403-431

23. McShane TO, Hirsch PD, Trung TC, Songorwa AN, Kinzig A, Monteferri B, O'Connor S (2011) Hard choices: Making tradeoffs between biodiversity conservation and human well-being. Biological Conservation 144(3):966-972 
24. Nadasdy P (1999) The Politics of TEK: Power and the Integration of Knowledge. Artic Anthropology 36:1-18

25. Nadasdy P (2005) The Anti-Politics of TEK: The Institutionalization of Co-Management Discourse and Practice. Anthropologica 47(2):215-232

26. Pinel SL, Pecos J (2012) Generating Co-Management at Kasha Katuwe Tent Rocks National Monument, New Mexico. Environmental Management 49(3):593-604.

27. Plummer R, Fitzgibbon J (2004) Co-management of Natural Resources: A Proposed Framework. Environmental Management 33:876-885.

28. Polo-Acuña J (2005) Etnicidad, conflicto social y cultura fronteriza In la Guajira (1700-1850). Ceso-Universidad de los Andes: Bogotá

29. Pomeroy RS, Berkes F 1997. Two to tango: the role of government in fisheries co-management. Marine Policy 21(5):465-480

30. Premauer J M (2013) Rights, Conservation and Governance: Indigenous Peoples - National Parks Collaboration in Makuira, Colombia. University of Manitoba. Unpublished PhD Thesis.

31. Premauer J M, Berkes F (2012) Colombia: Makuira, the cosmological centre of origin for the Wayúu people. In: Dudley N, Stolton S (ed) Protected Landscapes and Wild Biodiversity, IUCN-GTZ, Gland pp. 53-60

32. Riascos JC, Ormaza P, Zambrana G, Silva C (2008) Caracterización de las áreas indígenas y comunitarias para la conservación en Bolivia, Ecuador y Colombia. [http://www.iccaforum.org] Accessed 5 September 2012

33. Robbins P (2004) Political Ecology: A Critical Introduction. Blackwell Publishing, Oxford

34. Ross A, Sherman R, Snodgrass JG, Delcore HD (2011) Indigenous Peoples and the collaborative stewardship of nature: knowledge binds and institutional conflicts. Left Coast Press, Walnut Creek, USA.

35. Schwartzman S, Zimmerman B (2005) Conservation Alliances with Indigenous Peoples of the Amazon. Conservation Biology 19(3):721-727.

36. Singleton S (2000) Co-operation or Capture? The Paradox of Comanagement and Community Participation in Natural Resource Management and Environmental Policy-making. Environmental Politics 9(2):1-22

37. Spaeder J (2005) Co-management in a Landscape of Resistance: The Political Ecology of Wildlife Management in Western Alaska. Anthropologica 47(2):165-178

38. Spaeder J, Feit HA (2005) Co-management and Indigenous Communities: Barriers and Bridges to Decentralized Resource Management: Introduction. Anthropologica 47(2):147

39. Stevenson MG (2006) The Possibility of Difference: Rethinking Co-management. Human Organisation 65(2):167-180.

40. Tsing AL (2004) Friction: An ethnography of global connection Princeton University Press: Princeton

41. UAESPNN (2005) Plan de manejo Parque Nacional Natural Macuira 2005-2009. [http://www.parquesnacionales.gov.co/ PNN/portel/libreria/pdf/Macuira.pdf] Accessed 7 August 2013

42. Ungar P, Strand R (2012) Inclusive Protected Area Management in the Amazon: The Importance of Social Networks over Ecological Knowledge. Sustainability 4(12):3260-3278

43. Weitzner V, Manseau M (2001) Taking the Pulse of Collaborative Management in Canada's National Park Reserves: Voices from the Field. In: Harmon D (ed) Crossing Boundaries in Park
Management: Proceedings of the 11th Conference on Research and Resource Management in Parks and on Public Land. Hancock, George Wright Society, Michigan, pp. 253-259
Received: 06 February 2015

Accepted: 10 May 2015

Published: 11 June 2015 